\title{
Mikrozonasi Berdasarkan Data Mikrotremor dan Kecepatan Gelombang Geser di Kotamadya Yogyakarta
}

\author{
Aditya Yoga Purnamaa, b*, Budi Eka Nurcahyac, Kholis Nurhanafid, Radhitya Perdhanae \\ aDepartment of Physics Education, Universitas Sarjanawiyata Tamansiswa, Jalan Batikan UH.III/1043, \\ Yogyakarta 55167, Indonesia \\ bEducation Science Department, Concentration of Physics Education, Graduate School, Universitas Negeri \\ Yogyakarta, Jl. Colombo No. 1, Sleman, Yogyakarta, 55281, Indonesia \\ 'Department of Physics, Universitas Gadjah Mada, Yogyakarta, 55281, Indonesia, Sekip Utara \\ Bulaksumur Yogyakarta 55281 \\ dSMP IT Bina Insan Muara Wahau, Jl.Aneka rt No.08, Wanasari, Kec. Muara Wahau, Kabupaten Kutai \\ Timur, Kalimantan Timur 75655 \\ eProdi Geofisika, Universitas Tanjungpura, Pontianak, 78124, Kalimantan Barat, Jl. Prof.Dr.H.Hadari \\ Nawawi / Jendral Ahmad Yani, Pontianak \\ *Email : adityayoga@ustjogja.ac.id
}

(Diterima 22 Mei 2021; Disetujui 1 Desember 2021; Dipublikasikan 29 Desember 2021)

\begin{abstract}
Abstrak
Gempabumi Yogyakarta dengan magnitude 6,3 Skala Richter yang terjadi pada tahun 2006 menyebabkan kerusakan bangunan di Kota Yogyakarta dan sekitarnya. Kerusakan banyak terjadi di daerah sedimen Yogyakarta daripada di perbukitan Wonosari yang memiliki lapisan lebih keras. Kerusakan ini mengindikasikan adanya kontrol efek tapak lokal. Penelitian ini bertujuan untuk memetakan daerah rawan kerusakan gempabumi di Kotamadya Yogyakarta berdasarkan analisis kurva Horizontal-to-Vertical Spectral Ratio (HVSR) dan mengetahui litologi bawah permukaan berdasarkan ground profiles kecepatan gelombang geser $(V S)$ dengan metode inversi kurva HVSR. Penelitian dilakukan di Kotamadya Yogyakarta

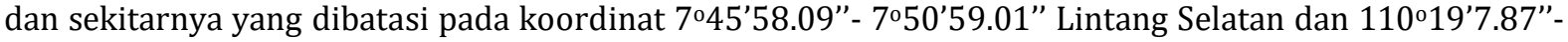
110²4'35.43" Bujur Timur. Data mikrotremor sebanyak 280 diolah menggunakan metode HVSR. Proses inversi HVSR juga dilakukan untuk memperkirakan model perlapisan tanah. Hasil dari penelitian menunjukkan bahwa nilai frekuensi dominan ( $f o$ ) di Kotamadya Yogyakarta dan sekitarnya berkisar antara 1,1-5,8 Hz, nilai amplifikasi $\left(A_{0}\right)$ berkisar antara 1-21, nilai Vs30 berkisar antara 210-376 m/s. Hasil inversi menunjukkan bahwa ketebalan lapisan sedimen di Kotamadya Yogyakarta dan sekitarnya berkisar antara 104 meter hingga 262 meter. Persebaran daerah lebih rentan secara seismik terdapat pada nilai amplifikasi tinggi sebesar 9-21 dengan rentang frekuensi 1,1-2,3 Hz yaitu di Kecamatan Sewon, Banguntapan dan Umbulharjo. Sebaran lokasi kejadian likuifaksi bersesuaian dengan nilai kecepatan gelombang geser rendah dengan rentang 210-262 m/s dengan jenis tanah sedang (SD) yaitu di Kecamatan Sewon, Banguntapan dan Umbulharjo.
\end{abstract}

Kata kunci: amplifikasi, inversi, HVSR, Kotamadya Yogyakarta, microtremor

\section{Latar Belakang}

Daerah yang sering terjadi gempabumi secara geografis relatif dekat dengan zona subduksi [1]. Pada zona subduksi tersebut terjadi tekanan, tarikan, dan pergeseran. Apabila batuan sudah mencapai batas elastisitasnya, maka batuan akan patah kemudian melepaskan energinya [2]. Energi yang terlepas tersebut dikenal sebagai gempabumi. Salah satu provinsi di Indonesia yang berdekatan dengan zona subduksi adalah Daerah Istimewa Yogyakarta. Selain itu, terdapat sesar di darat seperti sesar Opak yang menambah tingkat kerawanan terhadap gempabumi di Yogyakarta [3]. Kerusakan bangunan banyak terjadi di daerah sedimen Yogyakarta daripada di perbukitan Wonosari yang memiliki lapisan lebih keras.

Yogyakarta dilanda bencana gempabumi pada tahun 2006 dengan magnitudo 6,3 Skala Richter (SR) yang banyak memakan korban jiwa dan kerusakan bangunan [4]. Gempabumi Yogyakarta menewaskan lebih dari 5.700 jiwa dan lebih dari 200 ribu keluarga kehilangan tempat tinggal akibat gempabumi [5].

Penelitian ini menggunakan metode mikrotremor untuk memetakan daerah rawan kerusakan gempabumi di Kotamadya Yogyakarta berdasarkan analisis kurva Horizontal-to-Vertical Spectral Ratio (HVSR) dan mengetahui litologi bawah permukaan berdasarkan ground profiles 
kecepatan gelombang geser (Vs) dengan metode inversi kurva HVSR.

Berdasarkan uraian di atas, peneliti ingin mengetahui korelasi parameter frekuensi dominan, amplifikasi dan kecepatan gelombang geser terhadap tingkat kerusakan gempabumi di Kotamadya Yogyakarta dan sekitarnya berdasarkan data mikrotremor. Mitigasi bencana gempabumi dapat dilakukan dengan mengetahui daerah rawan terhadap gempabumi. Penelitian ini diharapkan mampu digunakan sebagai salah satu pertimbangan terhadap rancangan bangunan tahan gempa.

\section{Metodologi}

Metode geofisika yang dapat digunakan untuk memetakan potensi daerah rawan kerusakan akibat gempabumi adalah metode mikrotremor. Mikrotremor dapat digunakan dengan baik dalam memperkirakan efek tapak lokal. Mikrotremor merupakan getaran konstan dari tanah [6]. Metode ini sering digunakan karena biaya yang relatif murah dan tidak mengganggu lingkungan sekitar pengukuran. Mikrotremor juga dapat diterapkan dengan mudah di daerah perkotaan [7]. Penelitian dilakukan di Kotamadya Yogyakarta dan sekitarnya yang dibatasi pada koordinat 7045'58.09"'7050'59.01" Lintang Selatan dan 110¹9'7.87". 110²4'35.43" Bujur Timur. Data mikrotremor diperoleh dari pengukuran yang dilakukan oleh Balai Penyelidikan dan Pengembangan Teknologi Kebencanaan Geologi (BPPTKG) sebanyak 273 data menggunakan seismometer L43D Mark dan pengambilan langsung di lapangan sebanyak 7 titik menggunakan seismometer Guralp CMG-40TD. Salah satu metode geofisika yang dapat digunakan untuk memetakan potensi daerah rawan kerusakan akibat gempabumi adalah metode mikrotremor. Metode mikrotremor diolah menggunakan Horizontal-to-Vertical Spectral Ratio (HVSR). Data pengukuran kemudian diolah dengan menggunakan software Geopsy menghasilkan kurva HVSR. Kriteria reliabilitas pada kurva HVSR mengacu pada standar yang dibuat oleh SESAME European Research Project. Proses inversi HVSR juga dilakukan untuk memperkirakan model perlapisan tanah.

\section{Hasil dan Pembahasan}

Kerusakan bangunan yang diakibatkan oleh gempabumi diduga terkait dengan amplifikasi gelombang seismik. Amplifikasi adalah nilai puncak kurva HVSR. Menurut [8] dan [9] amplifikasi disebabkan karena adanya kontras impedansi yang artinya adanya perubahan kekompakkan batuan yang cukup besar antara lapisan sedimen dan lapisan bedrock. Hasil pengolahan HVSR seperti yang ditunjukkan pada Gambar 1 dihubungkan dengan data kerusakan bangunan akibat gempa bumi Yogyakarta tahun 2006 pada Tabel 1.

Tabel 1. Jumlah kerusakan bangunan akibat gempabumi Yogyakarta Tahun 2006 [10]

\begin{tabular}{|c|c|c|c|}
\hline \multirow{2}{*}{ Kecamatan } & \multicolumn{3}{|c|}{ Kerusakan Bangunan } \\
\cline { 2 - 4 } & Roboh & $\begin{array}{c}\text { Rusak } \\
\text { Berat }\end{array}$ & $\begin{array}{c}\text { Rusak } \\
\text { Ringan }\end{array}$ \\
\hline Sewon & 8281 & 8496 & 6004 \\
\hline Banguntapan & 5557 & 8232 & 7452 \\
\hline Umbulharjo & 2552 & 4875 & 4269 \\
\hline Kasihan & 1790 & 4557 & 11946 \\
\hline Gamping & 1695 & 3571 & 6444 \\
\hline Mergangsang & 1466 & 1934 & 1820 \\
\hline Kotagede & 1290 & 2002 & 2356 \\
\hline Mantrijeron & 608 & 1272 & 2381 \\
\hline Gondokusuman & 579 & 1009 & 1856 \\
\hline Wirobrajan & 177 & 764 & 1463 \\
\hline Danurejan & 99 & 389 & 717 \\
\hline Kraton & 91 & 389 & 953 \\
\hline Gondomanan & 74 & 3 & 388 \\
\hline Jetis & 73 & 593 & 1207 \\
\hline Pakualaman & 64 & 343 & 774 \\
\hline Tegalrejo & 60 & 583 & 1412 \\
\hline Ngampilan & 38 & 229 & 737 \\
\hline Gedongtengen & 15 & 175 & 897 \\
\hline
\end{tabular}

Kerusakan bangunan yang diakibatkan oleh gempabumi diduga terkait dengan amplifikasi gelombang seismik akibat efek tapak lokal (local site effect). Data kerusakan bangunan yang ditunjukkan pada Tabel 1 menunjukkan bahwa wilayah Kecamatan Sewon, Kecamatan Banguntapan, Kecamatan Umbulharjo dan Kecamatan Kasihan mengalami kerusakan bangunan akibat gempabumi Yogyakarta tahun 2006 paling banyak.

Data mikrotremor pada penelitian ini diperoleh dari pengukuran yang dilakukan oleh Balai Penyelidikan dan Pengembangan Teknologi Kebencanaan Geologi (BPPTKG) Yogyakarta tahun 2008 dan pengukuran di lapangan sebanyak 7 titik pengukuran. Data yang diperoleh dari pengukuran mikrotremor kemudian diolah menggunakan 
metode HVSR untuk mengkaji site effect. Hasil yang diperoleh dari kurva HVSR merepresentasikan kondisi geologi daerah penelitian dalam bentuk parameter frekuensi dominan dan faktor amplifikasi sedangkan dengan menggunakan inversi kurva HVSR dapat diketahui litologi bawah permukaan berdasarkan nilai kecepatan gelombang geser (Vs). Kurva hasil pengolahan termasuk dalam kategori reliable sesuai dengan ketentuan yang dibuat oleh [8]. Kurva HVSR di titik pengukuran banyak memiliki kemiripan bentuk, ini menunjukkan kondisi geologi daerah penelitian tidak berbeda jauh. Terdapat beberapa tipe bentuk kurva umum yang ditemukan di daerah penelitian yang ditunjukkan pada Gambar 1, Gambar 2, Gambar 3 dan Gambar 4 untuk masing-masing tipe. Tipe-tipe kurva tersebut antara lain tipe single peak (clear peak), double peak, flat $H / V$ curve, dan multi peak.

Kurva tipe pertama yaitu single peak (clear peak). Menurut [8] dan [11] single peak (tipe 1) menunjukkan adanya kontras impedansi antara lapisan sedimen terhadap lapisan bedrock. Kurva tipe 1 daerah penelitian ditunjukkan pada Gambar 1.

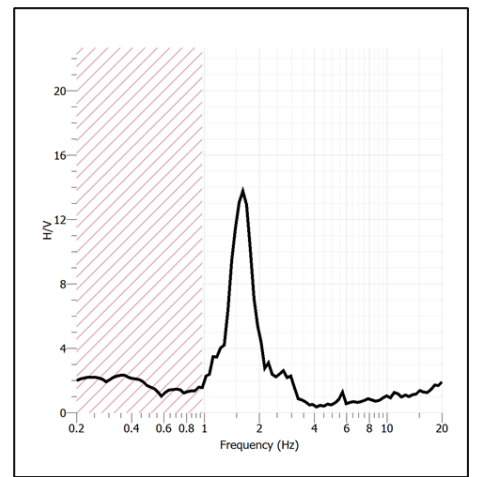

Gambar 1. Kurva HVSR tipe 1 single peak.

Pada Gambar 1 hasil pengolahan menggunakan software Geopsy yang menghasilkan frekuensi dominan pada sumbu $x$ dan faktor amplifikasi pada sumbu $y$.

Kurva tipe kedua yaitu double peak. Menurut [8] dan [11] double peak (tipe 2) menunjukkan adanya dua kontras impedansi antara dua lapisan sedimen terhadap lapisan bedrock. Puncak pada frekuensi rendah menunjukkan respon dari lapisan sedimen dalam, sedangkan puncak pada frekuensi tinggi menunjukkan respon dari lapisan sedimen dangkal seperti dijelaskan dalam [11]. Kurva tipe 2 daerah penelitian ditunjukkan dalam Gambar 2.

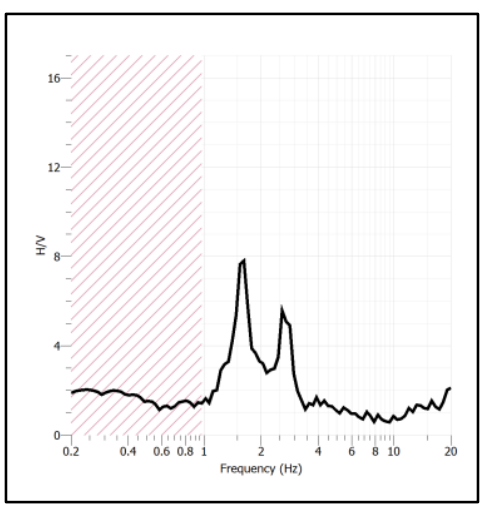

Gambar 2. Kurva HVSR tipe 2 double peak

Kurva tipe ketiga yaitu flat $H / V$ curve. Menurut [8] dan [11] flat $H / V$ curve (tipe 3) menunjukkan tanah di lokasi tersebut terdapat dua kemungkinan yaitu tanah keras atau tidak menunjukkan kontras impedansi antara lapisan sedimen dengan bedrock. Tipe 3 pada daerah penelitian ini tidak terlihat adanya peak seperti yang ditunjukkan pada Gambar 3.

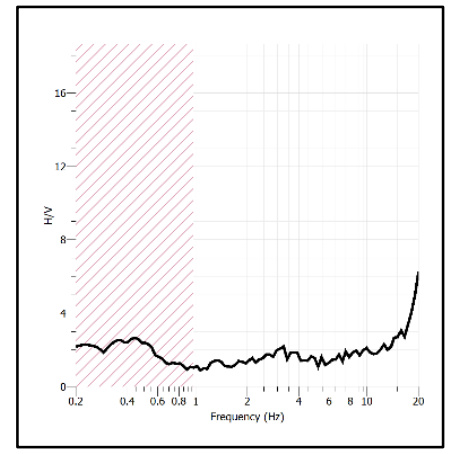

Gambar 3. Kurva HVSR tipe 3 flat curve.

Pada Gambar 3, kurva HVSR tipe flat curve berada pada titik diperbukitan wonosari tepatnya titik pengukuran Gunung Ireng.

Tipe kurva keempat yaitu multi peak atau memiliki puncak lebih dari dua. Tipe 4 pada daerah penelitian ditunjukkan pada Gambar 4.

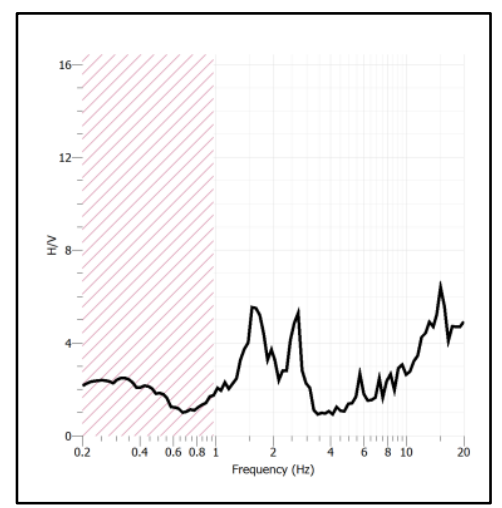

Gambar 4. Kurva HVSR tipe 4 multi peak. 
Pada Gambar 4 kurva tipe multi peak menunjukkan adanya banyak lapisan sedimen di lokasi tersebut. Sedangkan untuk persebaran tipe kurva HVSR di Kotamadya Yogyakarta dapat dilihat pada Gambar 5.

Kurva HVSR tipe 1 single peak ditunjukkan dengan warna merah yang tersebar di tengah Kotamadya Yogyakarta dan sebagian di selatan, timur, barat Kotamadya Yogyakarta. Kurva HVSR tipe 2 double peak ditunjukkan dengan warna biru yang tersebar di tengah Kotamadya Yogyakarta. Kurva HVSR tipe 3 flat curve ditunjukkan dengan warna kuning yang tersebar di 6 titik pengukuran, titik tersebut menunjukkan lapisan yang relatif keras dengan tidak adanya kontras impedansi terhadap bedrock. Sedangkan, kurva HVSR tipe 4 multi peak ditunjukkan dengan warna hijau yang tersebar di daerah penelitian terutama utara Kotamadya Yogyakarta.

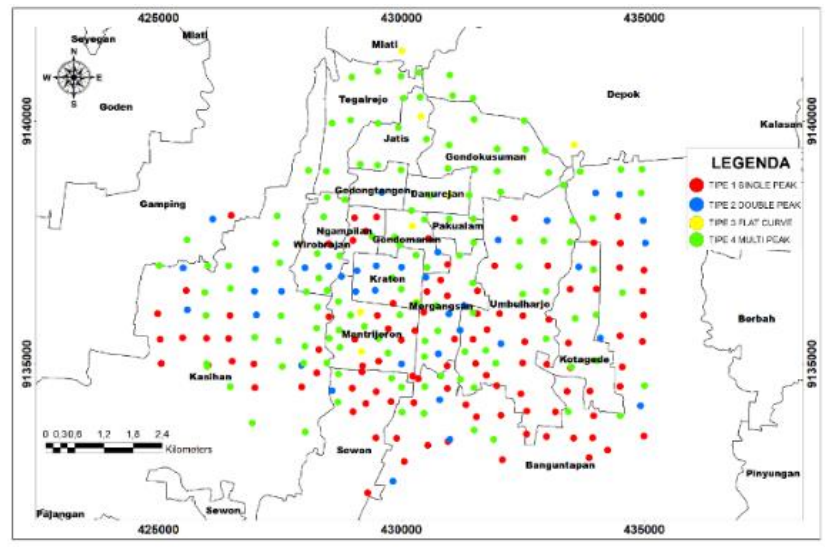

Gambar 5. Sebaran tipe-tipe kurva HVSR daerah penelitian.

Pada Gambar 5 setiap titik kurva HVSR dianalisis menggunakan syarat reliabilitas dari [8]. Kurva HVSR yang digunakan dalam penelitian ini memenuhi syarat reliabilitas. Pada penelitian ini dianalisis berdasarkan nilai frekuensi dominan, amplifikasi dan kecepatan gelombang geser $(V s)$.

Amplifikasi adalah nilai puncak kurva HVSR. Menurut [8] dan [9] amplifikasi disebabkan karena adanya kontras impedansi yang artinya adanya perubahan kekompakan batuan yang cukup besar antara lapisan sedimen dan lapisan bedrock. Hasil pengolahan HVSR yaitu amplifikasi dihubungkan dengan data kerusakan seperti penelitian sebelumnya dengan cara menumpang-tindihkan peta sebaran amplifikasi dan data kerusakan seperti ditunjukkan pada Gambar 6 .

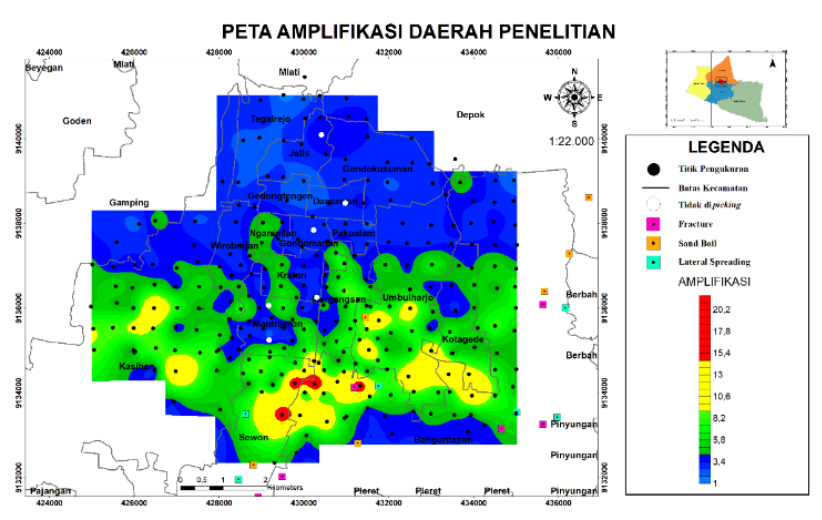

Gambar 6. Peta sebaran amplifikasi Kotamadya Yogyakarta.

Pada Gambar 6 nilai amplifikasi dalam penelitian ini dibagi dalam 4 tingkatan yaitu rendah, sedang, tinggi dan sangat tinggi. Dalam penelitian ini tingkat amplifikasi rendah dalam rentang 1-4, tingkat amplifikasi sedang 4-9, tingkat amplifikasi tinggi 9-15 dan tingkat amplifikasi sangat tinggi dalam rentang 15-21.

Berdasarkan klasifikasi tersebut diketahui bahwa daerah dengan nilai amplifikasi yang tinggi hingga sangat tinggi berada di wilayah Kecamatan Sewon, Banguntapan, Umbulharjo, Kotagede dan Kasihan. Peta sebaran amplifikasi menunjukkan sebagian besar daerah dengan tingkat amplifikasi rendah secara umum tersebar di utara Kotamadya Yogyakarta yaitu di wilayah Kecamatan Tegalrejo, Jetis, Gondokusuman, Gedongtengen, Danurejan, Pakualaman, Gondomanan, Gamping. Untuk Wilayah lainnya masuk kedalam tingkat amplifikasi sedang seperti Ngampilan, Wirobrajan, Kraton, Mantrijeron, Mergangsan. Gambar 6. menunjukkan adanya korelasi yang baik antara amplifikasi dan data kerusakan. Kerusakan akibat gempa Yogyakarta tahun 2006 terlihat pada nilai amplifikasi sedang hingga sangat tinggi.

Pada penelitian [12] dan [13] diketahui bahwa orientasi kerusakan bangunan di Yogyakarta membujur ke arah barat daya-timur laut. Daerah perbukitan tidak terlihat mengalami kerusakan atau hanya mengalami kerusakan yang sedikit. Daerah perbukitan umumnya memiliki lapisan yang lebih kompak atau keras. Pengukuran mikrotremor di lapisan keras dilakukan di Gunung Ireng Patuk Gunung Kidul. Pengukuran di Gunung Ireng digunakan sebagai pembanding dalam penelitian ini yang ditunjukkan pada Gambar 7 . 


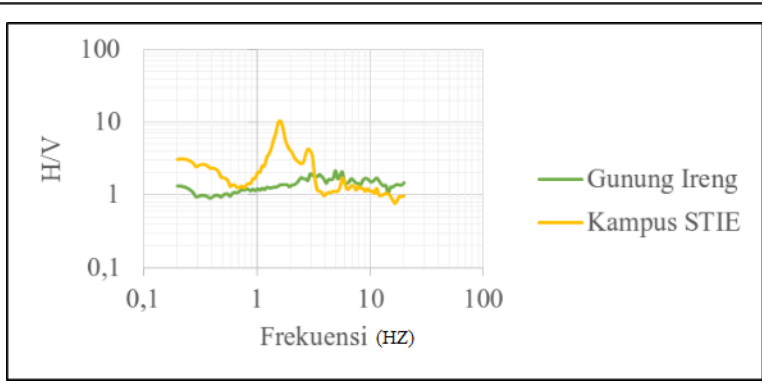

Gambar 7. Kurva HVSR pengukuran Gunung Ireng dan titik pengukuran Kampus STIE Kerjasama.

Pada Gambar 7 Kurva HVSR di Gunung Ireng tidak nampak adanya puncak. Hal ini menunjukkan bahwa di daerah ini tidak terdapat kontras impedansi sehingga tidak terjadi amplifikasi. Kurva yang ditunjukkan pada Gambar 7 di Gunung Ireng juga menggambarkan tingkat kerusakan rendah. Dengan kata lain, titik di gunung ireng tersebut menunjukkan daerah tidak rentan terhadap gempa bumi karena tidak adanya penguatan gelombang seismik yang melewati lapisan sedimen. Pengambilan data mikrotremor secara langsung juga dilakukan di bangunan yang mengalami kerusakan akibat gempabumi Yogyakarta 27 Mei 2006. Pengambilan data tersebut ditunjukkan pada Gambar 8.

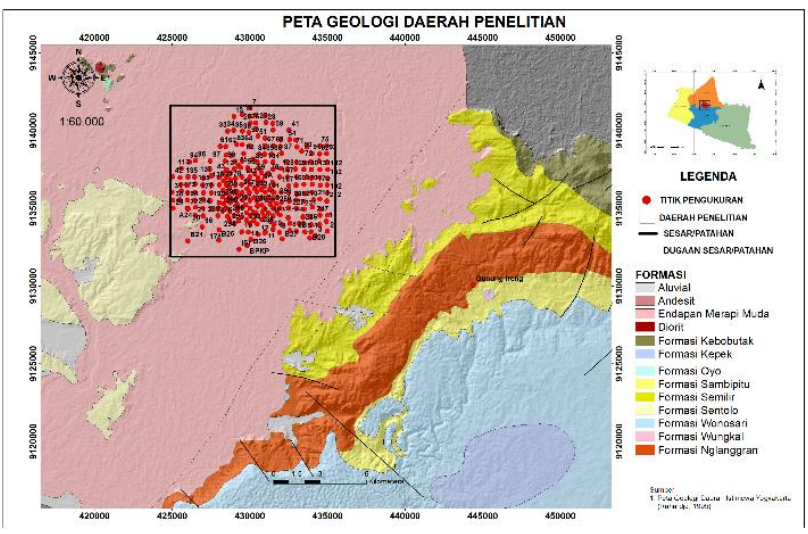

Gambar 8. Titik pengukuran langsung di Kotamadya Yogyakarta

Pada Gambar 8 ditunjukkan titik pengukuran di Kotamadya Yogyakarta dan titik pengukuran di Gunung Ireng yang digunakan sebagai pembanding. Hasil pengolahan data mikrotremor di beberapa titik bangunan yang mengalami kerusakan ditunjukkan pada Gambar 9.

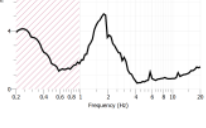

(a)

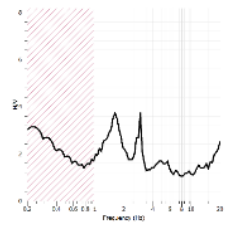

(d)

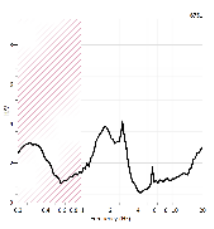

(b)

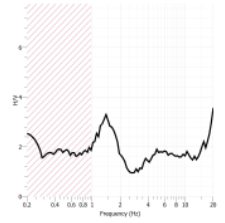

(e)

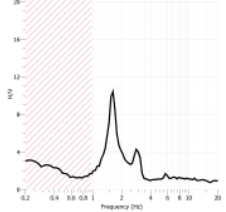

(c)

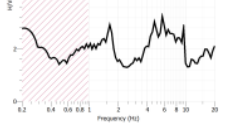

Gambar 9. (a) Titik pengukuran mikrotremor Kampus ISI Yogyakarta (b) Kantor BPKP (c) Kampus STIE Kerjasama (d) Purawisata (e) Amongrogo (f) Lippo Plaza.

Pada Gambar 9, faktor amplifikasi yang diperoleh adalah sebagai berikut: titik di sekitar Amongrogo diperoleh amplifikasi sebesar 3, di titik Lippo Plaza sebesar 2,8, di titik Purawisata sebesar 3,7, kantor BPKP sebesar 4, Kampus ISI Yogyakarta sebesar 5,3 dan Kampus STIE Kerjasama sebesar 10,5. Kurva HVSR pada Kampus STIE Kerjasama memiliki nilai amplifikasi yang lebih tinggi dibandingkan dengan amplifikasi pada 5 kurva HVSR di titik pengukuran lainnya. Bangunan yang roboh akibat gempabumi Yogyakarta tahun 2006 setidaknya memiliki nilai faktor amplifikasi lebih dari 4.

Pada penelitian ini juga menemukan bahwa waktu pengukuran tidak mempengaruhi pola frekuensi kurva HVSR di daerah penelitian. Terdapat titik pengukuran mikrotremor yang sama dengan BPPTKG yaitu di titik Kampus STIE Kerjasama, pengukuran tersebut menggunakan alat dan waktu pengukuran yang berbeda. Data mikrotremor titik tersebut ditunjukkan pada Gambar 10. Pengukuran tersebut dilakukan di titik 284 menggunakan alat Seismometer L43D Mark dengan waktu pengukuran 5 menit. Pengukuran yang dilakukan peneliti menggunakan Seismometer Guralp CMG-40TD dengan waktu pengukuran 1 jam 30 menit. Kedua pengukuran tersebut dilakukan pada siang hari. Kedua data tersebut menggunakan windowing 10,24 s dengan jenis window cosine tapered. 


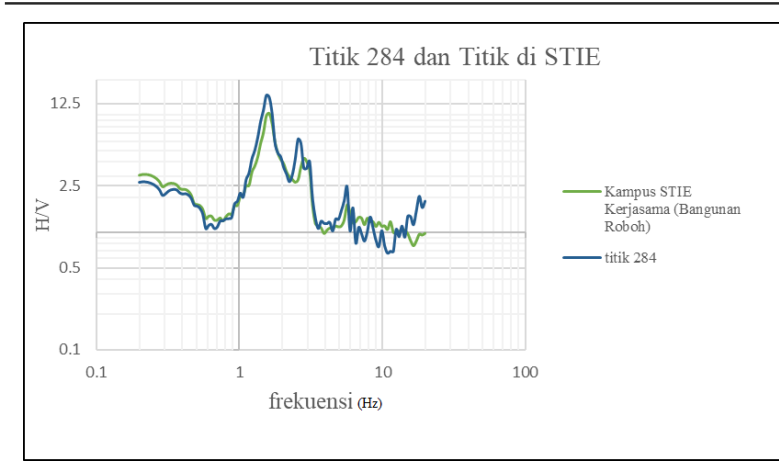

Gambar 10. Kurva HVSR di STIE Kerjasama

Gambar 10 merupakan perbandingan kurva hasil pengolahan di titik STIE Kerjasama. Hasil pengolahan Balai Penyelidikan dan Pengembangan Teknologi Kebencanaan Geologi (BPPTKG) Yogyakarta ditunjukkan oleh kurva berwarna biru. Sedangkan, pengukuran yang dilakukan oleh peneliti ditunjukkan oleh kurva berwarna hijau. Frekuensi dominan pada 2 kurva tersebut menunjukkan kesamaan yaitu pada frekuensi 1,5 Hz. Tetapi, sedikit berbeda pada puncak kurva HVSR. Nampak bahwa waktu pengukuran hanya berpengaruh terhadap nilai amplifikasi.

\section{Frekuensi Dominan}

Frekuensi dominan adalah frekuensi yang ajeg atau kerap muncul yang ditandai dengan nilai amplitudo yang besar. Nilai frekuensi dominan yang didapatkan dari kurva HVSR sebesar 1,1-5,8 Hz. Dalam penelitian ini frekuensi dominan dibagi kedalam 4 tingkatan yaitu frekuensi rendah, sedang, tinggi dan sangat tinggi. Frekuensi rendah berkisar antara 1,1-2,3 Hz, frekuensi sedang berkisar antara 2,3-3,5 Hz, frekuensi tinggi berkisar antara 3,5-4,7 Hz, sedangkan frekuensi sangat tinggi berkisar antara 4,7-5,8. Frekuensi rendah sebagian besar berada di Kotamadya Yogyakarta sebelah timur, sebagian di utara dan selatan Kotamadya Yogyakarta yaitu di Kecamatan

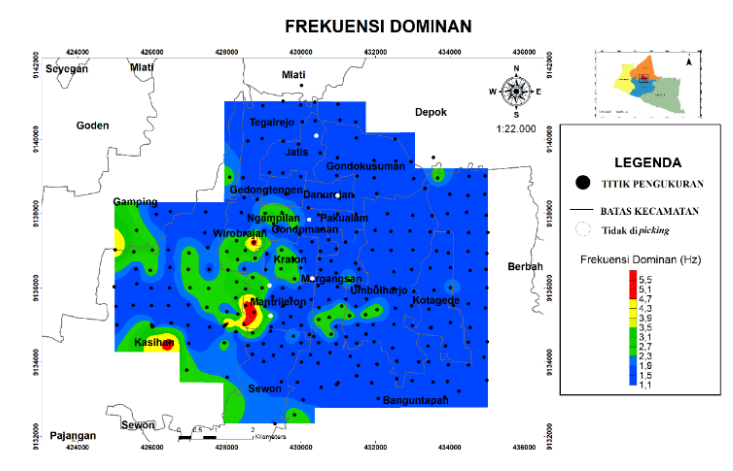

Gambar 11. Peta sebaran frekuensi dominan Kotamadya Yogyakarta.
Tegalrejo, Jetis, Gondokusuman, Danurejan, Gedongtengen, Pakualaman, Umbulharjo Gondomanan, Kotagede, Banguntapan, dan Sewon. Frekuensi sedang tersebar di beberapa titik di Kecamatan Kraton, Ngampilan, Gamping dan Mergangsan. Frekuensi tinggi dan sangat tinggi tersebar dibeberapa titik Kecamatan Wirobrajan, Mantrijeron dan Kasihan. Sebaran nilai frekuensi Kotamadya Yogyakarta ditunjukkan pada Gambar 11.

Nilai frekuensi juga menggambarkan ketebalan sedimen, frekuensi yang lebih tinggi menunjukkan lapisan sedimen yang tipis, sedangkan frekuensi rendah $(<0,1 \mathrm{~Hz})$ menunjukkan lapisan sedimen yang tebal $[9,14]$.

\section{Inversi Kurva HVSR}

Peta titik inversi dan lintasan inversi ditunjukkan pada Gambar 12. Titik data tersebut dapat mewakili daerah penelitian di Kotamadya Yogyakarta terutama daerah yang mengalami tingkat kerusakan tinggi. Hasil inversi tidak menunjukkan perbedaan yang jauh, ini menunjukkan litologi yang sama. Setelah itu, dibuatlah sayatan hasil inversi untuk mengetahui ketebalan lapisan sedimen.

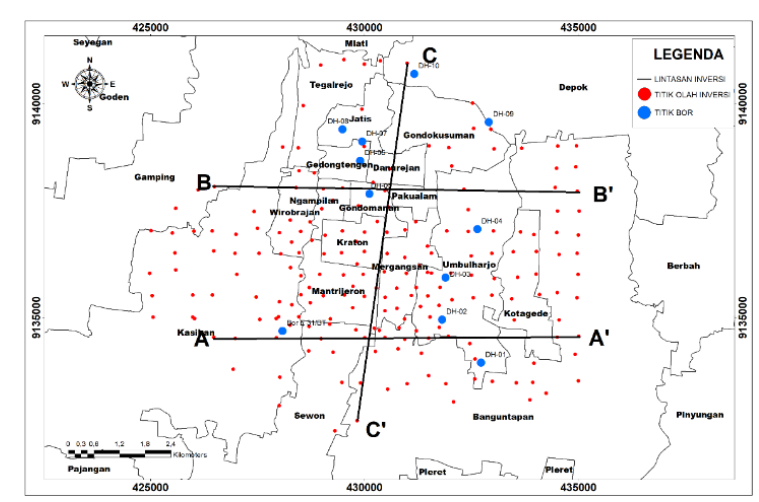

Gambar 12. Titik inversi dan lintasan inversi Kotamadya Yogyakarta

Korelasi data kerusakan dan kecepatan gelombang geser hingga kedalaman 30 meter (Vs30)

Gambar 12 adalah titik inversi yang ditunjukkan dengan warna merah, titik bor sebagai kalibrasi ditunjukkan dengan warna biru dan 3 lintasan inversi yaitu A-A', B-B' dan C-C'. Kurva HVSR yang diolah inversi sebanyak 202 data. Kecepatan gelombang geser merupakan salah satu parameter dalam menentukan pengklasifikasian jenis tanah dan batuan seperti yang ditunjukkan dalam SNI 1726:2012. Oleh karena itu, penting bagi 
perencanaan bangunan gedung untuk memperhatikan klasifikasi jenis tanah dan batuan ini. Kecepatan gelombang geser (Vs) juga digunakan sebagai indikator kekerasan batuan dalam geoteknik [15]. Klasifikasi batuan didasarkan pada nilai kecepatan gelombang geser hingga kedalaman 30 meter (Vs30). Nilai Vs30 di daerah penelitian memiliki rentang nilai 210 hingga 376 m/s yang ditunjukkan pada peta sebaran Vs30 Kotamadya Yogyakarta. Korelasi dilakukan antara data kerusakan akibat gempabumi Yogyakarta tahun 2006 dan Vs30 hasil inversi HVSR. Data kerusakan tanah seperti fracture, sandboil dan lateral spreading diperoleh dalam [12]. Likuifaksi biasa terjadi pada kedalaman air tanah dangkal [16]. Kedalaman air tanah yang dangkal (0-5) meter ditunjukkan pada titik 27, 26, 25, 24, 22, 21, 19, 18, 17, dan 10 Gambar 13. Semakin ke selatan kedalaman air tanah semakin dangkal, ini menunjukkan di bagian selatan Kotamadya Yogyakarta berpotensi terjadi likuifaksi. Kecamatan yang rentan terhadap likuifaksi yaitu di Kecamatan Umbulharjo, Banguntapan dan Sewon seperti ditunjukkan pada Gambar 13. Dibuktikan juga dengan adanya fenomena sand boil, lateral spreading, dan fractures. Sebaran nilai Vs30 Kotamadya Yogyakarta ditunjukkan pada Gambar 13.

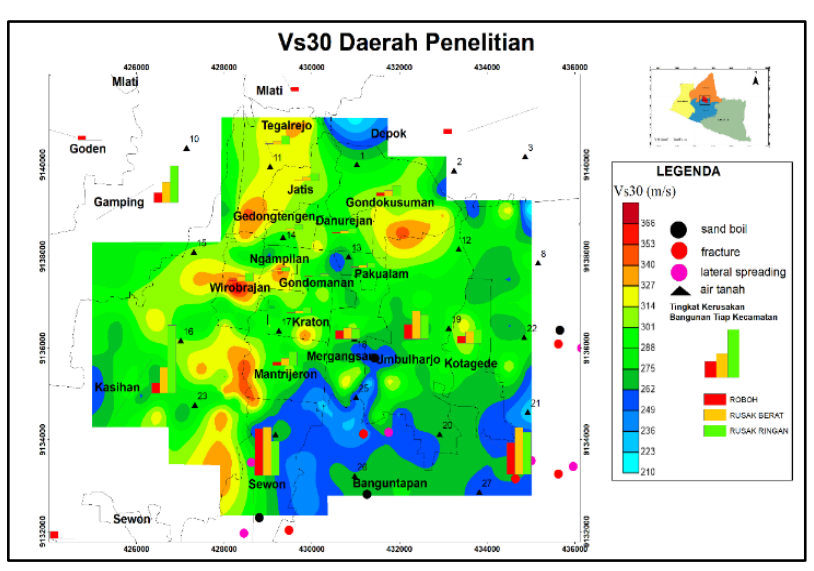

Gambar 13. Peta sebaran Vs30 Kotamadya Yogyakarta dan data kerusakan.

Gambar 13 merupakan peta sebaran Vs30 Kotamadya Yogyakarta yang dibagi kedalam 3 tingkatan yaitu rendah, sedang dan tinggi. Tingkat rendah ditunjukkan dengan warna biru yang bervariasi dari 210 hingga $262 \mathrm{~m} / \mathrm{s}$. Tingkat sedang ditunjukkan dengan warna hijau yang bervariasi dari 262 hingga $314 \mathrm{~m} / \mathrm{s}$. Tingkat tinggi ditunjukkan dengan warna kuning hingga merah dengan nilai 314 hingga $376 \mathrm{~m} / \mathrm{s}$. Peta sebaran Vs30 tersebut menunjukkan bahwa Kecamatan Sewon, Banguntapan, sebagian Kecamatan Mantrijeron dan Kecamatan Umbulharjo memiliki nilai Vs30 rendah dibandingkan kecamatan lainnya. Nilai Vs30 yang tinggi didominasi di sebelah barat Kotamadya Yogyakarta. Vs30 yang rendah memiliki korelasi terhadap kerusakan akibat gempa Yogyakarta tahun 2006 yang ditunjukkan oleh adanya fenomena sand boil (semburan pasir), fracture dan lateral spreading.

\section{Ketebalan Lapisan Sedimen}

Berdasarkan klasifikasi tanah menurut SNI 1726-2012 di daerah penelitian terdapat klasifikasi batuan keras (SA), batuan (SB), tanah keras (SC), tanah sedang (SD) dan tanah lunak (SE). Tanah lunak merupakan klasifikasi tanah dan batuan yang menjadi pertimbangan dalam perencanaan bangunan khususnya bangunan dengan lantai banyak. Ketebalan lapisan sedimen di Kotamadya Yogyakarta digambarkan dalam 3 lintasan inversi.

Secara keseluruhan, ketebalan lapisan sedimen di Kotamadya Yogyakarta bervariasi dari 104 meter hingga 262 meter. Menurut [17], ketebalan sedimen di Cekungan Yogyakarta berkisar antara 20 hingga 200 meter bahkan ada yang lebih. Berdasarkan ground profile yang didapatkan di Kotamadya Yogyakarta ketebalan lapisan pertama bervariasi dari 1 meter hingga 10 meter, lapisan kedua memiliki variasi ketebalan dari 3 meter hingga 38 meter, lapisan ketiga memiliki variasi ketebalan dari 2 meter hingga 120 meter, lapisan keempat memiliki variasi ketebalan dari 36 hingga 160 meter, lapisan kelima memiliki variasi ketebalan dari 8 hingga 141 meter. Sedangkan, kecepatan gelombang geser pada lapisan pertama bervariasi dari $100 \mathrm{~m} / \mathrm{s}$ hingga $166 \mathrm{~m} / \mathrm{s}$, lapisan kedua memiliki variasi dari $201 \mathrm{~m} / \mathrm{s}$ hingga 353 $\mathrm{m} / \mathrm{s}$, lapisan ketiga memiliki variasi dari $299 \mathrm{~m} / \mathrm{s}$ hingga $549 \mathrm{~m} / \mathrm{s}$, lapisan keempat memiliki variasi dari $530 \mathrm{~m} / \mathrm{s}$ hingga $881 \mathrm{~m} / \mathrm{s}$, lapisan kelima memiliki variasi dari $1054 \mathrm{~m} / \mathrm{s}$ hingga $1683 \mathrm{~m} / \mathrm{s}$. Nilai kecepatan gelombang geser tersebut menunjukkan bahwa lapisan pertama merupakan tanah lunak yang perlu adanya pertimbangan dalam perencanaan bangunan. Nilai kecepatan gelombang geser (Vs) antar titik pengukuran tidak berbeda jauh, ini karena Kotamadya Yogyakarta didominasi oleh formasi endapan merapi muda [16]. Penampang bawah permukaan Kotamadya Yogyakarta ditunjukkan pada Gambar 14. 


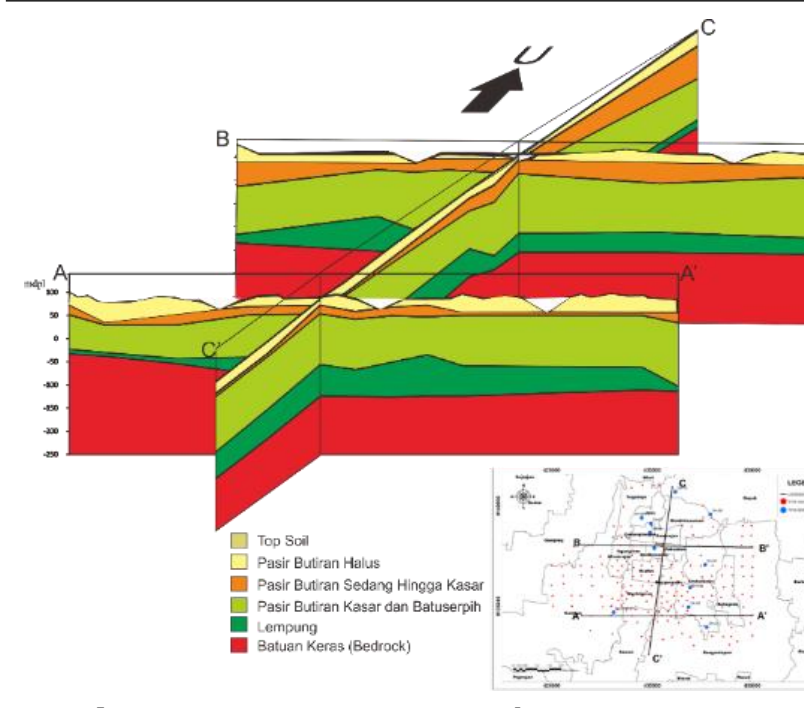

Gambar 14. Penampang lintasan inversi Kotamadya Yogyakarta.

\section{Kesimpulan}

Pemetaan daerah rawan kerusakan akibat gempa bumi Yogyakarta telah berhasil dilakukan dengan hasil yang berkorelasi antara data kerusakan bangunan dan hasil analisis menggunakan metode HVSR. Hasil dari penelitian menunjukkan bahwa nilai frekuensi dominan $\left(f_{o}\right)$ di Kotamadya Yogyakarta dan sekitarnya berkisar antara 1,1-5,8 Hz, nilai amplifikasi $\left(A_{0}\right)$ berkisar antara 1-21, nilai Vs30 berkisar antara 210-376 $\mathrm{m} / \mathrm{s}$. Hasil analisis menunjukkan bahwa terdapat 5 jenis lapisan di lokasi penelitian yaitu top soil, pasir berbutir halus, pasir berbutir sedang hingga kasar, pasir berbutir kasar dengan sisipan serpih dan lempung. Litologi bawah permukaan didominasi oleh sedimen dari formasi endapan merapi muda. Hasil inversi menunjukkan bahwa ketebalan lapisan sedimen di Kotamadya Yogyakarta dan sekitarnya berkisar antara 104 meter hingga 262 meter. Persebaran daerah lebih rentan secara seismik terdapat pada nilai amplifikasi tinggi sebesar 9-21 dengan rentang frekuensi 1,1-2,3 Hz yaitu di Kecamatan Sewon, Banguntapan dan Umbulharjo. Sebaran lokasi kejadian likuifaksi bersesuaian dengan nilai kecepatan gelombang geser rendah dengan rentang 210-262 m/s dengan jenis tanah sedang (SD) yaitu di Kecamatan Sewon, Banguntapan dan Umbulharjo.

\section{Ucapan Terima Kasih}

Terimakasih kepada Balai Penyelidikan dan Pengembangan Teknologi Kebencanaan Geologi (BPPTKG) memberikan kesempatan untuk menggunakan data.

\section{Daftar Pustaka}

[1] Susilanto, P., Ngadmanto, D., Sunardi, B. dan Rohadi, S., Analisis Kecepatan Gelombang Geser (Vs) Sebagai Upaya Mitigasi Bencana Gempabumi di Kulonprogo, Daerah Istimewa Yogyakarta, Jurnal Lingkungan dan Bencana Geologi, 10(2), pp. 41-50, 2018.

[2] Pratama, A., Arisondang, V. dan Sudarsono, B., Pengolahan Data GPS Kontinyu Jaringan Sugar (Sumatran GPS Array) Untuk Mengamati Deformasi Akibat Gempa Cekungan Wharton Sumatera, Dipa Ipteks, 1(1), pp. 35, 2013.

[3] Daryono., Indeks Kerentanan Seismik Berdasarkan Mikrotremor Pada Setiap Satuan Bentuk Lahan di Zona Graben Bantul Daerah Istimewa Yogyakarta, Disertasi, Universitas Gadjah Mada., Yogyakarta, 2011.

[4] Sunarjo., Gunawan, M.T. dan Pribadi, S., Gempabumi Edisi Populer., Badan Meteorologi Klimatologi dan Geofisika, Jakarta, 2012.

[5] Wuryanto, L. E. dan Hadi, S., Penilaian Awal Kerusakan dan Kerugian Bencana Alam di Yogyakarta dan Jawa Tengah., Bappenas, Yogyakarta, 2006.

[6] Motamed, R., Ghalandarzadeh, A., Tawhata, I. and Tabatabaei, S. H., Seismic Microzonation and Damage Assessment of Bam City, Southern Iran, Journal of Earthquake Engineering, 11(1), pp. 110-132, 2007.

[7] Wathelet, M., Jogmans, D. and Ohrnberger, M., Surface-wave Inversion Using a Direct Search Algorithm and its Application to Ambient Vibration Measurements, Near Surface Geophysics, 2, pp. 211-221, 2004.

[8] SESAME., Guidelines For The Implementation of the H/V Spectral Ratio Technique on Ambient Vibrations Measurements, Processing and Interpretation, Project No. EVG1-CT-2000-00026,European CommissionResearch General Directorate, 2004.

[9] Nakamura, Y., Clear Identification of Fundamental Idea of Nakamura's Technique and Its Applications, 12th World Conference on Earthquake Engineering, Auckland, 2000.

[10] Marjuki, B. and Yogafanny, E., Profil Kebencanaan Provinsi Daerah Istimewa Yogyakarta, BAPPEDA DIY, Yogyakarta, 2008.

[11] Kyaw, Z. L., Pramumijoyo, S., Husein, S., Fathani, T. F. and Kiyono, J., Seismic Behaviours Estimation of the Shallow and Deep Soil Layers Using Microtremor Recording and EGF Technique in Yogyakarta City, Central Java Island, Procedia Earth and Planetary Science, Yogyakarta, 2015.

[12] Soebowo, E., Tohari, A. dan Sarah, D., Studi Potensi Likuifaksi di Daerah Zona Patahan Opak Patalan Bantul Yogyakarta, Proseding 
POSITRON Vol. 11, No. 2 (2021), Hal. 86 - 94

Seminar Geoteknologi Kontribusi Ilmu Kebumian Dalam Pembangunan Berkelanjutan, Bandung, 2007.

[13] Anonim., Preliminary Damage AssessmentJava Earthquake. http://unosatmaps.web.cern.ch/unosataps/ID/UNOSAT Java EQ damage30may06 h ighres.jpeg, 2006.

[14] Parolai, S., Bormann, P. and Milkereit, C., New Relationships between Vs, Thickness of Sediments, and Resonance Frequency Calculated by the H/V Ratio of Seismic Noise for the Cologne Area (Germany), Bull of Seismological Society of America, 92(6), pp. 2521-2527, 2002.

[15] Huda, H. and Santosa, B.J, Pencitraan Struktur Permukaan Bawah Tanah Dengan
Menggunakan Analisa Kurva Dispersi Studi Kasus: Kampus Geomatika FTSP ITS Surabaya, Seminar Nasional Pasca Sarjana Institut Teknologi Sepuluh November, Surabaya, 2009.

[16] Ilham., Analisis Potensi Likuifaksi di Kotamadya Yogyakarta Berdasarkan Data Mikrotremor, Kedalaman Air Tanah, dan Data Bor, Tesis, Fakultas Matematika dan Ilmu Pengetahuan Alam, Universitas Gadjah Mada, Yogyakarta, 2018.

[17] Soebowo, E., Tohari, A. dan Sarah, D., Potensi Likuifaksi Akibat Gempabumi Berdasarkan Data CPT dan N-SPT di Daerah Patalan Bantul, Yogyakarta, Jurnal Riset Geologi dan Pertambangan, 19(2), pp. 85-97, 2009. 